\title{
Pendeteksian petanda kepuncaan glioblastoma multiforme
}

\author{
Yohana $^{1}$
}

\begin{abstract}
ABSTRAK
Glioblastoma multiforme (GBM) adalah tumor otak ganas yang memiliki populasi sel punca kanker yang dapat mempertahankan formasi tumor. Peranan sel punca kanker telah banyak dipelajari yang memiliki tanggung jawab terhadap resistensi dan rekurensi terapi GBM seperti radiasi dan kemoterapi. Beberapa petanda kepuncaan dapat dipakai diantaranya CD133, Nestin, A2B5, CD44, SOX2 and OCT4. Pemeriksaan histopatologi terhadap jaringan tumor yang dioperasi menjadi standar baku untuk menentukan derajat, tingkat keganasan, dan prognosis keganasan. Namun di sisi lain, kehadiran populasi sel punca yang memiliki sifat mampu memperbaharui diri dan mampu menginduksi pembentukan tumor memerlukan pemeriksaan yang lebih mendalam mengenai karakteristik biologi sel tumor. Pemeriksaan sel punca dilakukan menggunakan flowcytometry dan imunohistokimia.

Pemeriksaan petanda kepuncaan glioblastoma dilakukan dengan quantitative Reverse Transcriptase Real Time Polymerase Chain Reaction (qRT-PCR), Enzyme Linked Immunoabsorbent Assay (ELISA), Western Blot, Imunohistokimia dan flowcytometry.

Petanda CD133 ditemukan ekspresinya meningkat pada berbagai pemeriksaan. CD133 digunakan sebagai prognostik GBM.

Kata kunci: sel punca kanker, petanda, glioblastoma multiforme

${ }^{1}$ Departemen Biokimia, Fakultas Kedokteran Universitas Trisakti, Indonesia

Korespondensi:

Yohana

Departemen Biokimia, Fakultas

Kedokteran Universitas Trisakti, Jalan Kyai Tapa, Kampus B, Grogol, Jakarta Barat 11440, Indonesia

Email: dryohana@trisakti.ac.id

J Biomedika Kesehat 2020;3(1):39-45 DOI: $10.18051 /$ JBiomedKes.2020. v3.39-45

pISSN: 2621-539X / eISSN: 2621-5470

Artikel akses terbuka (open access) ini didistribusikan di bawah lisensi Creative Commons Attribution 4.0 International (CC-BY 4.0)
\end{abstract}




\section{ABSTRACT}

\section{Detection of cancer stem cell marker in glioblastoma multiforme}

Retinoblastoma is the most frequent intraocular malignancy experienced by neonates and children, with an incide Glioblastoma multiforme (GBM) is highly malignant brain tumor which has population cancer stem cells (CSCs) that could made tumor formation. Roles of cancer stem cells is widely studied which has responsible for resistance and recurrence in glioblastoma therapy such as radiation and chemotherapy. Few markers have been used in research for cancer stem cells such as CD133, Nestin, A2B5, CD44, SOX2, and OCT4. Recently Histopathological examination became commonly used in tumor resection for staging, grading, and prognostic in malignancy. In the other hand, the presence of fraction cancer stem cells which has self-renewal capacity and could induce tumor formation requires other examination that gave information about biologic tumor characteristic. Generally, detection for population cancer stem cells can be done by using flow cytometry and immunohistochemistry.

Identification cancer stem cells marker could be recognize by quantitative Reverse Transcriptase Real Time Polymerase Chain Reaction, ELISA, Western Blot, and immunohistochemistry and flow cytometry.

Expression CD133 marker higher in various observation. CD133 could be value as a prognostic factor in glioblastoma multiforme.

Keywords: cancer stem cell, glioblastoma multiforme

\section{PENDAHULUAN}

Glioma adalah tumor otak primer yang paling banyak ditemukan pada orang dewasa. (1) Glioma berasal dari sel glial. Hasil penelitian di Amerika Serikat memperlihatkan bahwa glioma mencakup $30 \%$ tumor pada sistem saraf pusat. (2) Glioma memiliki beberapa subtipe sel antara lain astrositoma, oligodedroglioma dan ependimoma. Etiologi glioma sampai saat ini masih tidak diketahui pasti. Berdasarkan klasifikasi histopatologi WHO tentang morfologi sel tumor, glioma dikelompokkan menjadi 4 grade, yaitu grade I, II , III dan IV. ${ }^{(3)}$ Grade I yaitu tumor pilositik astrositoma yang memiliki karakteristik tumbuh secara lambat. Grade II yaitu tumor tersusun atas astrositoma, oligodendroglioma, dan campuran oligodendroglioma. Tumor ini terdiri dari sel yang berbentuk astrosit (bintang) yang atipikal dan tumbuh menyebar secara infiltratif. Glioma grade I dan II dikategorikan sebagai tumor glioma tingkat rendah. Glioma grade III terdiri dari sel oligodendroglioma dan sel astrositoma yang bersifat anaplastik. Tumor jenis ini lebih agresif karena mengandung sel-sel yang memiliki aktifitas mitosis yang tinggi dan bersifat anaplastik. Glioma grade IV terdiri dari glioblastoma multiforme dan gliosarcomas. Glioblastoma multiforme (GBM) memiliki karakteristik terdiri dari jaringan nekrosis dan mikrovaskular yang mampu berproliferasi secara aktif. Tumor grade III dan IV merupakan glioma dengan tingkatan tertinggi. ${ }^{(3)}$ GBM seperti tumor otak lainnya, memiliki gejala defisit fokal neurologis yang berasal dari kompresi tumor dan infiltrasi sel tumor ke jaringan sekitarnya, penekanan sel tumor ke pembuluh darah otak dan peningkatan tekanan intrakranial. Manifestasi klinis yang terlihat seperti sakit kepala yang tidak diketahui penyebabnya dan keluhan bertambah berat. Sakit kepala tersebut disertai dengan kejang yang bersifat umum, parsial ataupun kompleks. Defisit fokal neurologis yang terlihat diantaranya gangguan mental, neuropati dan gangguan kognitif..$^{(4)}$

GBM memiliki ketahanan hidup kurang dari 15 bulan. ${ }^{(5)}$ Terapi konservatif glioma seperti operatif, kemoterapi dan radiasi memberikan dampak yang minimal terhadap prognosis glioma. GBM memiliki fraksi sel dengan karakteristik fenotip sel punca neuron yang ditemukan pada otak. Sel punca neuron terdiri dari sel radial progenitor, sel progenitor neuron dan sel glial. Sel radial progenitor bersifat multipoten dengan kapasitas mampu memperbaharui diri yang tidak terbatas, sedangkan sel progenitor neuron dan sel glial bersifat unipoten dengan kemampuan memperbaharui diri yang terbatas. ${ }^{(6)}$ Glioma stem cells (GSCs) memiliki karakteristik kemampuan memperbaharui diri, bersifat multipoten dan mampu menginduksi pembentukan tumor. GSCs terdiri dari kumpulan sel heterogen yang berfungsi sebagai awal pembentukan tumor. GSCs memiliki peranan terhadap resistensi terapi konvensional dan rekurensi dari penyakit tersebut. ${ }^{(7)}$ Berdasarkan The Cancer Genome Atlas (TCGA) tahun 2008 GBM diklasifikasikan menjadi beberapa subkelas berdasarkan petanda keganasan yaitu klasikal, mesenkimal, neural, dan proneural. $^{(8)}$ Petanda ini dapat digunakan sebagai prognostik, prediksi 
ketahanan hidup, dan respon terapi glioma. Sudah terbukti bahwa karakteristik biologi tumor, lingkungan mikro tumor dan kegagalan terapi konvensional memainkan peranan keberadaan GSCs. ${ }^{(7)}$

Hasil penelitian sebelumnya memperlihatkan bahwa sel punca kanker menginduksi populasi sel embrio fibroblas tikus untuk aktif berproliferasi dan memiliki sifat pluripoten. Pada penelitian tersebut melibatkan beberapa faktor transkripsi diantaranya: OCT4, SOX2, c-Myc, Klf4. Sel punca kanker pada tumor disimpulkan sebagai populasi sel yang heterogen, bersifat memperbarui diri dan dapat memperlihatkan pertumbuhan sel tumor secara terus menerus. ${ }^{(9)}$ Selain penelitian di atas, penggunaan sekretom sel punca mesenkim mampu meningkatkan ekspresi mRNA SOX2 dan OCT4 pada sel glioblastoma T98G. ${ }^{(10)}$ Lebih jauh juga dibuktikan bahwa penggunaan sekretom sel punca mesenkim adiposa dan umbilical meningkatkan ekspresi mRNA ALDH1A1 dan ALDH1A3 pada sel kanker payudara manusia. ${ }^{(1)}$ Beberapa petanda dapat diajukan sebagai indikator kepuncaan diantaranya CD133, SOX2, Nestin, dan A2B5. ${ }^{(12,13)}$ Sampai saat ini petanda CD133 disarankan sebagai petanda kepuncaan pada glioblastoma, meskipun keakuratan CD133 sebagai petanda tunggal masih dipertanyakan. Hal tersebut disebabkan antara lain karena perbedaan sel kultur, penggunaan hewan coba yang kurang baik, dan ketidakmampuan antibodi untuk medeteksi CD133. Namun pemeriksaan terhadap petanda tersebut dapat memberikan informasi prognostik terapi dan progresivitas glioblastoma. ${ }^{(14)}$

\section{Molekul CD133}

CD133, dikenal sebagai AC133, adalah 5-glikoprotein transmembran, sebuah antigen yang terekspresi di permukaan membran sel hematopoetik. ${ }^{(5)}$ Glikoprotein tersebut memiliki berat $120 \mathrm{kDa}$ dan terdiri dari 865 asam amino
(Gambar 1). CD133 terletak pada mikrovili dan membran plasma sel yang mengalami protrusi. ${ }^{(15)}$ Lebih jauh dilaporkan bahwa CD133 dapat meregulasi proliferasi dan kemampuan pembentukan koloni formasi tumor. ${ }^{(6)}$ Gen yang mengkode CD133 yaitu PROM1 (Gambar 2). Gen tersebut memiliki fungsi diferensiasi sel, transisi sel epitel ke sel mesenkim, dan merupakan petanda neural stem sel pada manusia. Pada beberapa penelitian dengan menggunakan hewan coba tikus menunjukan bahwa gen yang mengkode CD133 terletak pada kromosom 5 (5b3) sedangkan pada manusia CD133 merupakan produk single copy gen pada kromosom 4 (4p15.33). ${ }^{(16,17)}$ Petanda CD133 ditemukan meningkat pada berbagai jenis tumor diantaranya tumor otak, tumor prostat, tumor payudara, tumor kolorektal, tumor hati, tumor paru, tumor ovarium dan tumor solid lainnnya. ${ }^{(14)}$

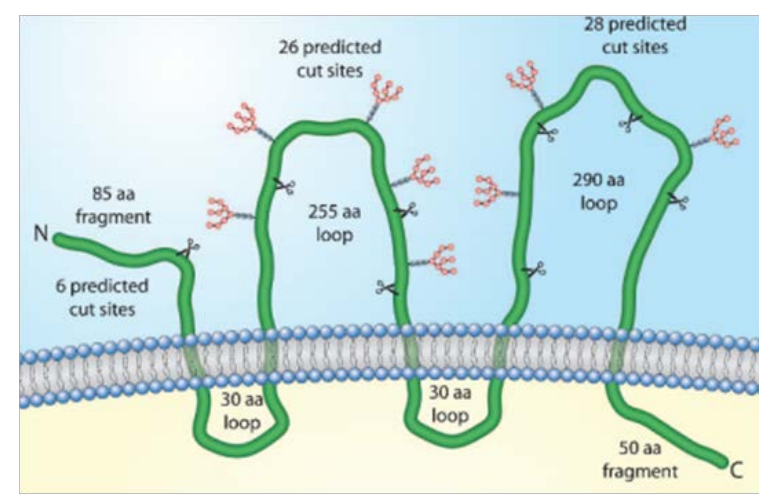

Gambar 1. Letak protein CD133 pada membran sel ${ }^{(15)}$

Hasil penelitian sebelumnya mendemostrasikan populasi CD133 yang diisolasi dari tumor otak manusia yang kemudian diperbanyak pada tikus yang memiliki imunitas yang rendah. Menggunakan metoda cell sorting pada flowcytometry diperlihatkan bahwa berbagai variasi sel, CD133+ memiliki aktifitas telomerase yang tinggi dengan kemungkinan aktifitas kepuncaan. Populasi CD133+ ditemukan juga pada sel punca neural dan sel progenitor. Jumlah

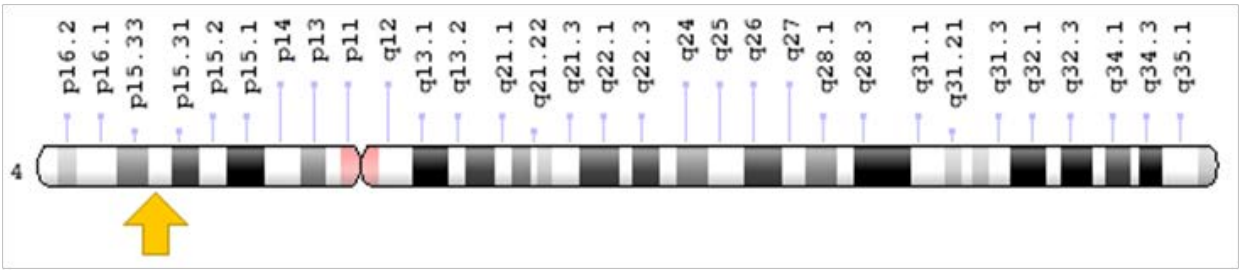

Gambar 2. Lokasi PROM1 gen ${ }^{(17)}$ 
populasi CD133+ yang meningkat berhubungan dengan prognosis penyakit yang buruk. ${ }^{(8)} \mathrm{Kadar}$ mRNA PROM1 yang ditemukan meningkat mampu memisahkan GBM ke berbagai tingkatan. Setelah melalui terapi radiasi dan kemoterapi, sel GBM memiliki prosentase CD133+ yang tinggi jika dibandingkan sel tumor asal. Populasi CD133+ diindikasikan sebagai kelompok sel yang memiliki sifat kepuncaan. ${ }^{(18)}$ Hasil penelitian lain memperlihatkan bahwa populasi CD133+ mampu membentuk formasi tumor melalui neurosphere yang terbentuk pada kultur. Penelitian ini juga menunjukan peningkatan proliferasi, deferensiasi dan migrasi sel pada CD133+ yang disuntikan pada neonates mencit. ${ }^{(19)}$

\section{Pemeriksaan petanda kepuncaan}

Pemeriksaan petanda kepuncaan Glioblastoma multiforme (GBM) dapat dilakukan dengan metode diantaranya; Quantitative Reverse Transcriptase Real Time Polymerase Chain Reaction (qRT-PCR), Enzyme Linked Immunoabsorbent Assay (ELISA), Western Blot, Imunohistokimia, dan Flowcytometry.

\section{Quantitative Reverse Transcriptase Real Time Polymerase Chain Reaction (qRT-PCR)}

Salah satu hasil penelitian dengan qRT-PCR memperlihatkan ekspresi petanda CD133 dan CD44 yang meningkat pada tumor dibandingkan dengan jaringan normal. Penelitian tersebut menemukan ekspresi mRNA CD133 dan CD44 pada tumor kolorektal dan tumor hepar meningkat dibandingkan jaringan normal. Hasil penelitian menunjukan petanda CD133 memiliki peranan terhadap pertumbuhan tumor sedangkan CD44 memiliki peranan terhadap invasi tumor ke jaringan sekitar. ${ }^{(20)}$

\section{Enzyme Linked Immunoabsorbent Assay (ELISA)}

CD133 yang merupakan glikopreotein transmembran diduga memiliki sifat kepuncaan yang kuat, serta betanggung jawab atas pembentukan tumor baru dan pemeliharaan tumor. Terdapat penelitian yang mengajukan CD133 sebagai salah satu taget terapi tumor. Mulanya protein CD133 dilakukan isolasi yang kemudian diekspresikan pada bakteri E.coli. CD133 yang telah dipurifikasi mampu dijadikan sebagai bahan kompetitif untuk mendeteksi suatu antibodi tertentu. CD133 yang terekspresi pada cloning vector mampu bersaing sebagai bahan uji untuk mendeteksi antibodi CD133 pada manusia. ${ }^{(21)}$

\section{Western Blot}

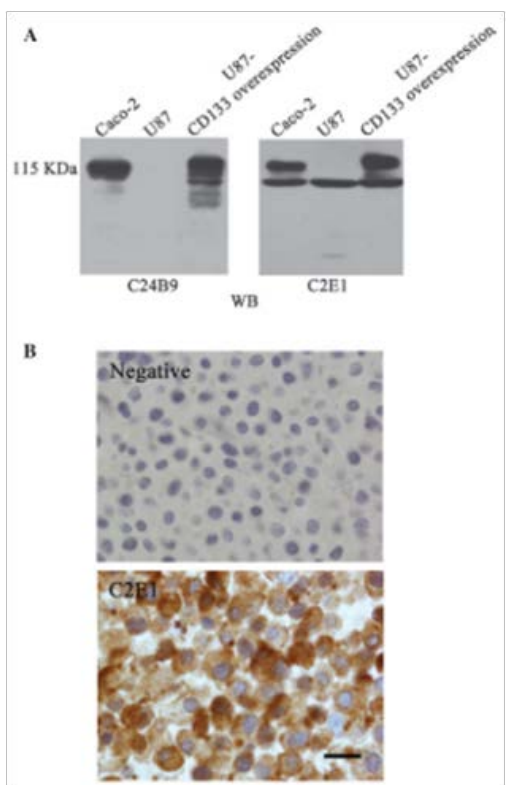

Gambar 3. Metode Western Blot dan imunohistokimia A. Pendeteksian CD133 pada galur sel glioma Caco-2, U87, dan U87-CD133 overexpression dengan Western Blot.

B. Pewarnaan Imunohistokimia dilakukan dengan penggunaan antibodi $\mathrm{C} 2 \mathrm{E} 1$ untuk mengetahui ekspresi CD133 pada galur sel glioblastoma U87. Gambar bagian atas memiliki kesimpulan negatif terhadap CD133 dan gambar bawah hasil positif pada CD133. Skala bar $20 \mu \mathrm{m}$ (22) $^{(22}$

Identifikasi dan ekspresi CD133 dibuktikan melalui penelitian eksperimen sebelumnya yang bertujuan mendeteksi ekspresi CD133 pada galur sel U87 dengan menggunakan antibodi monoklonal CD133. Penelitian ini menggunakan dua macam antibodi C2E1 dan C24B9 yang merupakan antibodi komersil. Didapatkan hasil positif pada kedua antibodi untuk mengetahui ekspresi molekul CD133 pada galur sel Caco-2 sebagai kontrol, U87, dan U87-CD133 overexpression. Pada Gambar 3A, identifikasi CD133 dibandingkan dengan penanda lain memiliki berat molekul $115 \mathrm{kDa}$ yang mendekati protein CD133 yaitu 120 kDa. ${ }^{(22)}$ Hasil penelitian lainnya menyebutkan Nestin adalah filament intermediet yang merupakan petanda sel punca. Ekspresi Nestin pada Western Blot ditemukan sebanding dengan penanda kontrol. Identifikasi CD133 juga dibuktikan dengan metode immunofluorescence pada jaringan tumor dengan pewarnaan anti-nestin serum yang memberikan 
hasil positif. ${ }^{(23)}$ Penelitian ini menyimpulkan ekspresi petanda CD133 dan Nestin dalam jaringan tumor memainkan peranan terhadap kemampuan sel memperbaharui diri secara imortal. ${ }^{(24)}$

\section{Imunohistokimia}

Hasil eksperimen Wang et al. untuk mendeteksi CD133 dengan antibodi C2E1 pada galur sel U87-CD133 overexpression menunjukan ekspresi CD133 positif pada galur sel glioblastoma U87-CD133 dibanding sel kontrol. Pada Gambar 3B menunjukan gambaran pleiomorfik berbagai sel dengan inti sel yang mengalami mitosis. Hal ini menunjukan CD133 dapat dipakai sebagai petanda untuk mendeteksi kepuncaan. ${ }^{(22)}$ Setelah pengangkatan tumor pemeriksaan histopatologi menjadi rutin dilakukan untuk mementukan derajat dan tingkat penyakit. Di sisi lain metode pewarnaan imunohistokimia mampu memberikan informasi karakteristik sel dan jaringan yang telah diterapi serta prognosis dari perjalanan penyakit dan rekurensi penyakit. ${ }^{(25)}$

Populasi CD133 tidak hanya didapatkan pada GBM namun ekspresinya ditemukan meningkat pada adenokarsinoma pankreas. Penelitian lain mendeteksi petanda seperti Nestin, CD133, dan Ki67 yang ekspresinya meningkat pada adenokarsinoma pankreas dibandingkan jaringan normal. Ekspresi CD133 dan Nestin menunjukan korelasi positif dengan petanda Ki67 pada adenokarsinoma pankreas. Peningkatan ekspresi ketiga protein tersebut menunjukan peningkatan aktivitas proliferasi sel, deferensiasi sel, dan penyebaran secara invasif. ${ }^{(26)}$

\section{Flowcytometry}
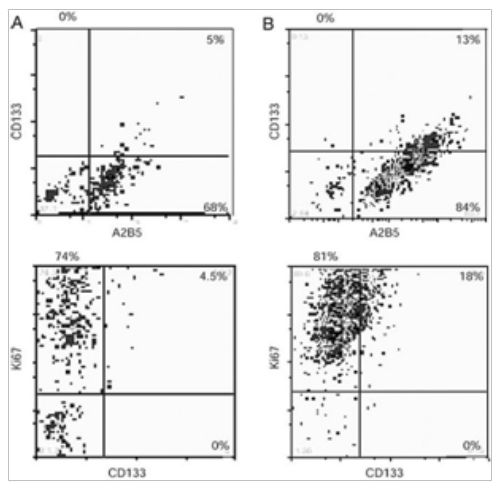

Gambar 4. Aplikasi Flowcytometry pada petanda CD133 dan A2B5 pada populasi sel glioblastoma

Flowcytometry menganalisis sphere Glioblastoma A2B5, CD133, dan ekspresi Ki67. Gambar A. GBM pasase 15: 5\% dari A2B5+/CD133+, 68\% dari A2B5+/CD133-, 27\% dari A2B5-/CD133-. Gambar B. GBM pasase 13: 13\% dari $\mathrm{A} 2 \mathrm{~B} 5+/ \mathrm{CD} 133+, 84 \%$ dari A2B5+/CD133-, 3\% dari A2B5-/ CD133-. Semua sel CD133+ mengekspresikan antigen Ki67 tetapi bagian major Ki67 tidak mengekspresikan CD133.

Beberapa sel GBM CD133- tidak berproliferasi. ${ }^{(27)}$

Penelitian lainnya menggunakan metoda flowcytometry membuktikan petanda A2B5 pada jaringan glioma manusia memiliki peranan dalam pembentukan formasi tumor. Terlihat pada Gambar 4, populasi sel glioblastoma dengan A2B5+ memiliki kemampuan memperbaharui diri, membentuk formasi tumor baru pada nude mice, dan mampu berdeferensiasi. Populasi sel CD133+ diduga memainkan peranan terhadap sifat keganasan tumor sedangkan populasi sel A2B5+ memiliki peranan terhadap inisiasi pembentukan sel tumor, kemampuan memperbaharui diri, dan pemeliharaan sel GBM. Dilaporkan juga sebagian populasi sel A2B5+ adalah populasi sel CD133+. (27)
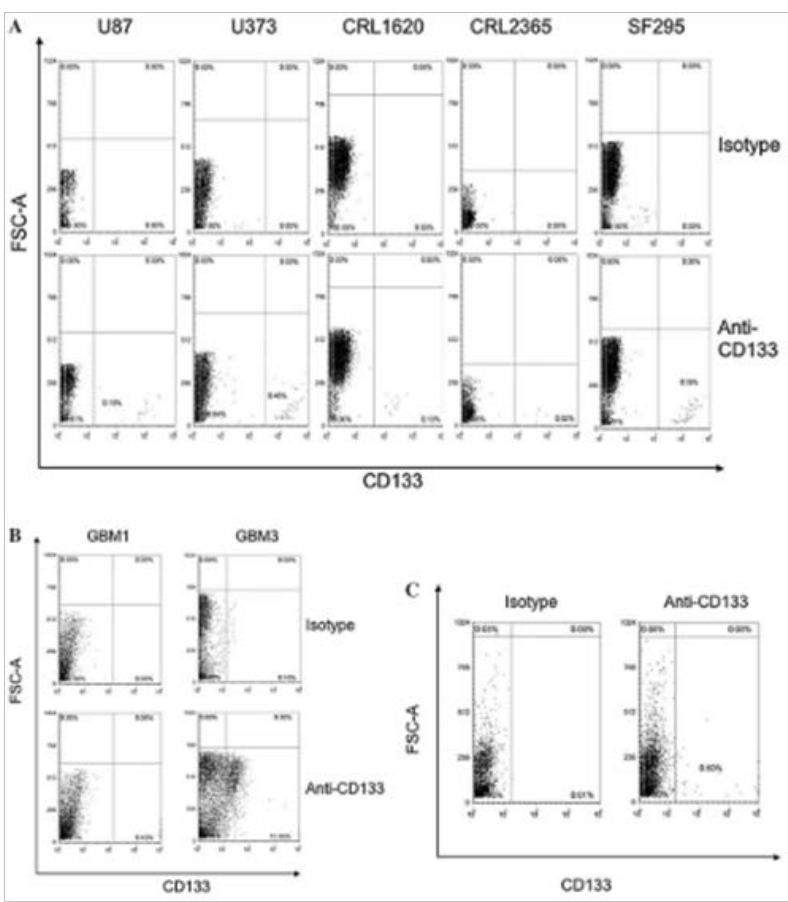

Gambar 5.

A.Pemeriksaan ekspresi CD133+ dengan Flowcytometry pada berbagai sel glioblastoma manusia. B. Pemeriksaan ekspresi CD133 pada galur sel glioblastoma yang established. C. Ekspresi CD133 pada galur sel glioblastoma GL261 tikus.

Hasil serupa didapatkan oleh peneliti lainnyayangmengamatiekspresiCD133 padagalur sel GL261 pada tikus. Pada Gambar 5 dibuktikan populasi CD133+ ditemukan pada berbagai galur sel glioblastoma. Ditemukan juga populasi sel CD133+ pada galur sel GL261 mampu melakukan pembentukan formasi tumor dan mengadakan 
deferensiasi sel. Populasi CD133+ pada galur sel GL261 juga menunjukan sifat protumorigenik ketika sel tersebut diinjeksikan secara intracranial ke tikus untuk membetuk tumor. Ditemukan juga bahwa populasi sel CD133+ memiliki resistensi obat terhadap populasi sel CD133-. ${ }^{(28)}$

\section{KESIMPULAN}

Berbagai jenis petanda kepuncaan pada tumor diantaranya: CD133, CD44, SOX2, OCT4, A2B5, Nestin dan sebagainya dapat dideteksi melalui pemeriksaan jaringan, sel kultur, maupun hewan coba. Ekspresi CD133 yang meningkat dapat dideteksi dan diukur dengan berbagai metoda dari tingkat gen hingga protein. CD133 dapat digunakan sebagai penentu prognostik glioblastoma multiforme (GBM).

\section{REFERENSI}

1. Hardiany NS, Wanandi SI, Yohana. TNFR, TRAF2, NF- $\kappa$ B mRNA Levels of Glioblastoma Multiforme Cells Treated by Conditioned Medium of Umbilical Cord-derived Mesenchymal Stem Cells. Indones Biomed J. 2019;(2):217-24. doi: 10.18585/inabj.v11i2.722

2. Jiang H, Cui Y, Wang J, et al. Impact of epidemiological characteristics of supratentorial gliomas in adults brought about by the 2016 world health organization classification of tumors of the central nervous system. Oncotarget. 2017;8(12):20354-61. doi: 10.18632/ oncotarget. 13555

3. Louis DN, Perry A, Reifenberger G, et al. The 2016 World Health Organization Classification of Tumors of the Central Nervous System : a summary. Acta Neuropathol. 2016; 131 (6): 803 20. doi: 10.1007/s00401-016-1545-1

4. Hanif F, Muzaffar K, Perveen K, et al. Glioblastoma Multiforme : A Review of its Epidemiology and Pathogenesis through Clinical Presentation and Treatment. Asian Pac J Cancer Prev. 2017;18(1):3 9. doi: 10.22034/APJCP.2017.18.1.3

5. Xu HS, Qin XL, Zong HL, et al. Cancer stem cell markers in glioblastoma - an update [Internet]. Eur Rev Med Pharmacol Sci. 2017;21(14):3207-11. Available from: https://www.europeanreview.org/ article/13142 PubMed PMID: 28770964

6. Bradshaw A, Wickremsekera A, Tan ST, et al. Cancer Stem Cell Hierarchy in Glioblastoma Multiforme. Front Surg. 2016;3:1-16. doi: 10.3389/fsurg.2016.00021

7. Liebelt BD, Shingu T, Zhou X, et al. Glioma Stem Cells: Signaling, Microenvironment and Therapy. Stem Cells Int. 2016:1-10. doi: 10.1155/2016/7849890

8. Ludwig K, Kornblum HI. Molecular markers in glioma. J Neurooncol. 2017;134(3):505-12. doi: 10.1007/s11060-017-2379-y

9. Zhao W, Li Y, Zhang X. Stemness-related Markers in Cancer. Cancer Transl Med. 2017;3(3):87-95. doi: $10.4103 /$ ctm.ctm 6916

10. Hardiany NS, Huang P, Dewi S, et al. Analysis of pluripotency marker expression in human glioblastoma multiforme cells treated with conditioned medium of umbilical cord-derived mesenchymal stem cells. F1000Res. 2018. doi: 10.12688/f1000research.13154.1

11. Wanandi SI, Purnamawati, Tamara A, et al. Analysis of ALDHA1 and ALDHA3 gene mRNA expression in adipose - derived stem cells (ASCs) and Umbilical cord derived stem cells (UCSCs). Indones Biomed J. 2018;10(3): 290-6. doi: 10.18585/inabj.v10i3.477

12. Munthe S, Petterson SA, Dahlrot RH, et al. Glioma cells in the tumor periphery have a stem cell phenotype. PLoS One. 2016;11(5):1-16. doi: 10.1371/journal.pone.0155106

13. Dahlrot RH, Kjaer Hermansen S, Hansen S, et al. What is the clinical value of cancer stem cell markers in gliomas? [Internet] Int J Clin Exp Pathol. 2013;6(3):334-48. PubMed PMID: 23412423

14. Glumac PM, Lebeau AM. The role of CD133 in cancer: a concise review. Clin Transl Med. 2018;7(1):18. doi: 10.1186/s40169-018-0198-1

15. Sakariassen $P \varnothing$, Immervoll $H$, Chekenya $M$. Cancer Stem Cells as Mediators of Treatment Resistance in Brain Tumors: Status and Controversies.Neoplasia. 2007;9(11):882-92. doi: 10.1593/neo.07658

16. Li Z. CD133: A stem cell biomarker and beyond. Exp Hematol Oncol. 2013 Jul 1;2(1):17. doi: 10.1186/2162-3619-2-17

17. Han Z, Papermaster DS. Identification of Three Prominin Homologs and Characterization of Their Identification of three prominin homologs and characterization of their messenger RNA expression in Xenopus laevis tissues [Internet]. Mol Vis. 2011;17: 1381-96. Available from: http://www.molvis.org/molvis/v17/a155/ PubMed PMID: 21655362

18. Singh SK, Clarke ID, Terasaki $M$, et al. Identification of a cancer stem cell in human brain tumors [Internet]. Cancer Res. 2003;63(18):58218. Available from: https://cancerres.aacrjournals. org/content/63/18/5821.long PubMed PMID: 14522905

19. Uchida N, Buck DW, He D, et al. Direct isolation of human central nervous system stem cells. Proc Natl Acad Sci U S A. 2000;97(26): 14720-5. doi: 10.1073/pnas.97.26.14720

20. Jing F, Kim HJ, Kim $\mathrm{CH}$, et al. Colon cancer stem cell markers CD44 and CD133 in patients with colorectal cancer and synchronous hepatic metastases. Int J of Oncol. 2015(46);1582-8. doi: 10.3892/ijo.2015.2844

21. Xia J, Zhang Y, Qian J, et al. Isolation, identification and expression of specific human CD133 antibodies. Sci Rep 3, 3320 (2013). doi: 10.1038/srep03320

22. Wang D, Guo Y, Li Y, et al. Detection of CD133 expression in U87 glioblastoma cells using a novel anti-CD133 monoclonal antibody. Oncol Lett. 2015;9(6):2603-8. doi: 10.3892/ol.2015.3079

23. Dahlstrand J, Collins VP, Lendahl U. Expression of the Class VI Intermediate Filament Nestin in Human Central Nervous System Tumors [Internet]. Cancer Res. 2000;52: 5334-42. Available from: https://cancerres.aacrjournals.org/ content/52/19/5334.long PubMed PMID: 1382841

24. Neradil J, Veselska R. Nestin as a marker of cancer stem cells. Cancer Sci. 2015;106(7):803-11. doi: 
$10.1111 /$ cas. 12691

25. Wei B, Wang Z, Liang J, et al. TRAF2 is a Valuable Prognostic Biomarker in Patients with Prostate Cancer. Med sci Monit. 2017(23);4192-204. doi: 10.12659/MSM.903500

26. Alshenawy HA. Significance of Expression of Cancer Stem Cell Markers CD133 and Nestin in Pancreatic Intraepithelial Carcinomainvasive Adenocarcinoma Sequence. Appl Immunohistochem Mol Morphol. 2020 Mar;28(3):205-212. doi: 10.1097/ PAI.0000000000000722.

27. Tchoghandjian A, Baeza N, Colin C, et al. A2B5 cells from human glioblastoma have cancer stem cell properties. Brain Pathol. 2010;20(1):211-21. doi: 10.1111/j.1750-3639.2009.00269.x

28. Wu A, Oh S, Wiesner SM, et al. Persistence of CD133+ Cells in Human and Mouse Glioma Cell Lines: Detailed Characterization of GL261 Glioma Cells with Cancer Stem Cell-Like Properties. Stem Cells and Development. 2008; 17(1):173-84. doi: $10.1089 /$ scd. 2007.0133 